Makale türü / Article type: Araştırma / Research

\title{
Rekreatif Eğlencede Yeni Bir Tür: Kaçış ve Korku Evi Oyunları¹
} ***

\section{A New Type of Recreational Entertainment: Escape and Horror House Games}

\author{
Öğr. Gör. Erdoğan Ekinci \\ Artvin Çoruh Üniversitesi, Arhavi MYO, erdoganekinci@artvin.edu.tr; (ORCID: 0000-0002- \\ 6816-9393) \\ Öğr. Gör. Fatih Mehmet Parlar
}

Artvin Çoruh Üniversitesi, Arhavi MYO, fatihmehmetparlar@artvin.edu.tr; (ORCID: 00000002-3401-4078)

Öğr. Gör. Burak Güvenman

Artvin Çoruh Üniversitesi, Arhavi MYO, guvenman@artvin.edu.tr; (ORCID: 0000-00034242-0882)

Öğr. Gör. Oğuzhan Yıldız

Artvin Çoruh Üniversitesi, Borçka Acarlar MYO, oguzhanyildiz@artvin.edu.tr; (ORCID: 0000-0002-0220-1450)

Ferizan Parlar

Karadeniz Teknik Üniversitesi, EBE, ferizanparlar@gmail.com; (ORCID: 0000-0002-76842920)

\section{Özet}

$\mathrm{Bu}$ araştırma, yeni bir rekreatif eğlence türü olarak son yıllarda ülkemizde de ilgi görmeye başlayan kaçış ve korku evi oyunlarının literatürle de desteklenerek mevcut durumunun incelenmesi amacıyla gerçekleştirilmiştir. Çalışmada öncelikle literatür taraması yapılarak korkunun psikolojik, sosyolojik boyutları analiz edilmiş, sonraki aşamada ise kaçış ve korku evi işletmeleri ziyaret edilerek uygulama aşamaları gözlemlenmiştir. Çalışma sonucunda kaçış ve korku evi oyunlarının korku çekiciliği, korku pazarlaması, eğlence ihtiyacı boyutlarında işlev kazandığı, kaçış ve korku evi işletmelerinin bahsi geçen bu boyutlarda dizayn edilerek hizmet sunduğu anlaşılmıştır. Bir rekreatif etkinlik türü olarak kaçış ve korku evi oyunlarının ülkemizde popülerliğini arttırdığı, bu alanda bireyler için farklı bir eğlence etkinliği

${ }^{1}$ Bu makale, 2018 yılı Nisan ayında İstanbul'da gerçekleştirilen I. Uluslararası Beden Eğitimi, Spor, Rekreasyon ve Dans Kongresinde sözlü bildiri olarak sunulmuştur. 
sunduğu ve girişimciler için de yeni bir rekreasyon işletmeciliği firsatı verdiği düşünülmektedir.

Anahtar Kelimeler: Kaçış ve Korku Evi, Oyun, Rekreasyon

JEL Sinıflandırması: L83

\begin{abstract}
This research has been carried out in order to examine the present situation supported by the literature of escape and horror house games, which have recently started to attract interest in our country as a new type of recreational entertainment. In the study, firstly the literature was searched and the psychological and sociological dimensions of the horror were analyzed. In the next stage, the stages of implementation were observed by visiting the escape and fear house operators. As a result of the study, it was understood that escape and horror house plays serve in fear dimension, horror marketing, entertainment need dimensions, escape and horror home businesses are designed and served in these dimensions. As a type of recreational activity, escape and horror house games have increased the popularity of our country, this area has provided a different entertainment activity for the individuals and for entrepreneurs it is thought that it gives a chance of operating a new recreation.
\end{abstract}

Keywords: Escape and Horror House, Game, Recreation JEL Classification: L83

\title{
GİRIŞ
}

Korku, tarih öncesi çağlardan buyana, tüm varlıklarda görülen önemli bir duygudur. Korku, tüm varlıklarda adeta genetik bir miras gibi bir sonraki kuşağa aktarılır. Korkunun günümüzde var olduğu gibi gelecekte de varlığını sürdürmeye devam edeceği yadsınamaz bir gerçektir. İlk insanların hissettiği bireysel korkular günümüzde de devam etmekle birlikte, küreselleşmiş dünyada özelliklede teknoloji alanında yaşanan gelişmeler ile birlikte daha geniş bir duygusal yelpazede karşımıza çıkmaktadır. Korku çok güçlü, çok normal, hayatta kalmayı ve yaşamı sürdürmeyi sağlayan yararlı bir duygudur (Kayac1, 2016).

Kaçış ve korku evi oyunları ilk kez 2007 yılında Japonya'da ortaya çıkmış ve kısa bir zamanda tüm dünyada olduğu gibi ülkemizde de büyük bir 
ilgi görmüştür. Başlangıçta, İstanbul, Ankara ve İzmir gibi büyükşehirlerde ortaya çıkan kaçış ve korku evi işletmeleri günümüzde 15-20 bin nüfuslu ilçelerde dahi talep görerek açılmakta ve insanlara farklı bir rekreatif eğlence türü sunmaktadır. Kaçış ve korku evi oyunları, insanlar için yeni bir rekreatif eğlence türü deneyimleme firsatı sağlarken, girişimciler için ise eğlence sektöründe yeni bir yatırım firsatı sunmaktadır.

Korku, heyecan, adrenalin sevenleri eşsiz deneyimlere çağıran kaçış ve korku evi oyunları, özellikle hem sosyal medyadaki reklamlar ve hem de kulaktan kulağa aktarılan bilgiler ile ziyaretçilerini henüz ağırlamadan korkutmaya başlamaktadır. Korkunç hikâyelerle süslü kendilerine ait bir tema oluşturan kaçış ve korku evi işletmeleri, özel olarak tasarlanan oyun mekânlarında adrenalin yaşamak isteyen ziyaretçilerini maceraya çağırmaktadır. Hatta bazı kaçış ve korku evi işletmeleri "yeterince cesur musun?" gibi meydan okumalarla işi cesaret gösterisine çevirmektedir. Bunun sonucunda kaçış ve korku evi oyunları daha da yayılmakta ve her geçen gün yeni bir kaçış ve korku evi işletmesi açılmaktadır (Üçhisarlı, 2017). Yeni bir rekreatif eğlence türü olarak bireyleri boş zamanlarında korkuturken eğlendiren ve eğlendirirken zekâ oyunları ile düşünmelerini sağlayan kaçış ve korku evi oyunlarına duyulan ilgi dikkat çekmektedir. Bu bilgiler ışığında, çalışmanın amacı yeni bir rekreatif eğlence türü olarak kaçış ve korku evi oyunları hakkında ilgili literatürden ve internet kaynaklarından elde edilen bilgiler ile konuya ilişkin kavramsal çerçeve oluşturularak bilgiler vermektir.

\section{KORKU}

Korku tehlike düşüncesinin uyandırdığg duygusal bir reaksiyondur. Doğal olarak insanlar, tehlikeli olarak değerlendirdikleri durumlardan mümkün olduğu kadar uzak kalmak, eğer bu durumun içindelerse de kaçmak, kendini korumak isterler. Dolayısıyla korku içerdiği tehlike düşüncesi neticesinde, beraberinde korunma, kaçma davranışı getiren bir duygudur (Gençöz, 1998). Diğer duygular gibi korku da birçok farklı içerikten oluşan çok boyutlu deneyimlerden biridir. Genellikle tehdit edici bir duruma verilen tepki olarak tanımlanır. Daha önce geçirdiği kötü bir denemeden sonra birinden veya bir şeyden zarar gelebileceği kanısı, bu duygudaki en temel 
tetikleyicidir (Dinçer, 2017). Birçok alanda araştırma konusu olan korku, terimsel olarak faklı tanımlara sahiptir. Türk Dil Kurumu korkuyu; "bir tehlike veya tehlike düşüncesi karşısında duyulan kaygı, üzüntü”, "kötülük gelme ihtimali, tehlike, muhatara" ve "gerçek veya beklenen bir tehlike ile yoğun bir acı karşısında uyanan ve coşku, beniz sararması, ağız kuruması, kalp, solunum hızlanması vb. belirtileri olan veya daha karmaşık fizyolojik değişmelerle kendini gösteren duygu" olarak tanımlamaktadır (TDK, 2017). Bir başka tanıma göre ise korku, kişinin bütünlüğünü tehdit edeceğini düşündüğü bir durum karşısında yaşadığı duygudur. Dolayısıyla korku, içinde bulunduğumuz duruma değil, bu durum için geliştirdiğimiz düşüncelerimize verdiğimiz bir reaksiyon olarak tanımlamaktadır (Özdemir, 2016).

Korku denildiğinde akla gelen ilk kelime ise fobidir. Fobi kelimesi, Yunan mitolojisinde var olduğuna inanılan korku tanrısı Fobos'tan (Phobos) gelmektedir. Bir tür kaygı bozukluğu türü olan fobi, kişinin belirli bir durum, canlı-cansız varlık veya mekâna yönelik olarak hissettiği ileri düzeydeki korku hali olarak tanımlanmaktadır (Kaynak, 2016). Sadece Eski Yunanda değil eski toplumların tümünde birbirine benzer birçok korku motifi görmek mümkündür. Batı mitolojisinde, "kurt adam, cadı, vampir, hayalet vb." isimler ile adlandırılan korku motifleri, Türk mitolojisinde de "tepegöz, hortlak, gulyabani vb." gibi çeşitli motifle karşımıza çıkar. Batım toplumlarında özellikle Ortaçağ Avrupa'sına bakıldığında toplumun en büyük korkusu olarak karşımıza cadı kavramı çıkmaktadır. Cadı, eski çağlardan beri efsanelerde, destanlarda ve masallarda yaşayagelen çok sayıdaki varlıktan biridir. Cadı, birtakım gizli kuvvetlerin, doğaüstü varlıklar ve güçlerden miras yoluyla elde edildiği inancına dayanan pratiklere ilişkin bir kavramlaştırmadır (Aslan Karaküçük, 2010). Türkçede Cadılar Bayramı olarak bilinen "Halloween" ise, batı dünyasında her yılın 31 Ekim akşamında kutlanan önemli bayramlardan biridir. Tarihsel süreç içerisinde Cadılar Bayramı adı verilen kutlamanın inanç ve pratikler açısından zenginleşmesini sağlamış, son aşamada da pagan dönemlerden kalan bu ritüeller dini motiflerle birleştirilerek Hristiyanlık içerisinde yerini almıştır (Coşkun ve Zöhre, 2014). 
Türk mitolojisine bakıldığında ise, en önemli şeytani varlık Erlik'tir. Erlik, kaşı, gözü, ve saçı kara, yaban domuzu dişli, kara ata veya öküze binen, yılan kamçılı, kan gibi parlak yüzlü şeklindeki vücut tasviri ne kadar korkunç olduğu hakkında bir fikir verebilir (Kaya, 2017). Türk edebiyatına bakıldığında, ilk yazılı Türk metni olan Orhun Kitabeleri'nde ve tarihteki ilk Türkçe sözlük olarak kabul gören Divânu Lugâti't-Türk'te korku ile ilgili kelime ve metinler bulunmaktadır. Örneğin, Orhun Kitabeleri'ne bakıldığında Bilge Kağan Abidesi doğu cephesinde, "Onu korkutayım deyip ordu sevk ettim", Tonyukuk Abidesi ikinci taş batı cephesinde "Çok diye niye korkuyoruz” ve Tonyukuk Abidesi ikinci taş güney cephesinde "İnel Kağan'a, korkup ......", şeklinde korku ile ilgili cümleler yer almaktadır (Ergin, 2013). Divânu Lugâti't-Türk'te ise "korkuld1=korkuldu, korkunç=korkunç, korkund1=korku duymak-korkusunu saklamak ve korkışd1=korktu” şeklinde korku ile ilgili kelimeler bulunmaktadır (TDK, 2018).

\section{KORKU ÇEKİCILİĞİ}

Genelde insanlar belli bir rutinin içine sıkışmış hayatları yaşıyor ve korkunç bir durumla karşılaştıklarında belli bir süreliğine de olsa bu rutinden kurtulup tamamen o ana odaklanabiliyorlar (FPDEM, 2017). Korku insanoğlunun en evrensel içgüdüsüdür ve bunu istemek bile insana haz verir. Böylece beden ve zihin bütünlüğü doyuma ulaşır. Yani korku ve haz birbiriyle ilişkilidir hatta biri diğeri için tamamlayıcı bir işlev görür (Canabakan, 2017). Sosyal psikolog Jeffrey Goldstein'1n editörlügünü üstlendiği Why We Watch: The Attractions of Violent Entertainment (Neden İzleriz: Şiddet İçerikli Eğlencenin Cazibesi) isimli çalışmada, "şiddet içerikli imgelere yönelmemizin temel nedenlerinden biri içinde yaşadığımız uygarlıktır. Modern toplum yapısının bizlere planlı, önceden kestirilebilir ve heyecan duygusundan uzak bireysel yaşantılar sunduğunu söylemek mümkün. $\mathrm{Bu}$ durum birey için heyecan arayışını beraberinde getirmekte. Korku içeren eğlence araçlarına yönelme ise bireyin heyecan arayışının bir sonucu olarak görülmektedir" (GKabacaoğlu, 2016).

Korku ve ikna kavramı içinde oluşan korku çekiciliği, bireylere önerilen ya da tavsiye edilen herhangi bir duruma karşı tedbir almaları, almadıkları taktirde başlarına gelebilecek olumsuz olaylara dikkati çekmek 
yoluyla, korku öğesini kullanarak kitleleri ikna etmeye çalışan bir tür ikna yöntemidir. Korku çekiciliği kavramının bireylerin tutum ve davranışları üzerindeki etkisi fark edilince, pazarlamadan siyasete kadar geniş bir yelpaze de korku çekiciliği kavramı kullanılmaya başlanmıştır (Mazıcı ve Çakı, 2018). Teknolojik gelişmeler ve yenilikler, sosyal hayatın karmaşıklığı ve hızı, çarpık bir fiziksel çevre, şiddetli suç tırmanışı, uluslararası çatışmalar ve nükleer savaş tehdidi gibi birçok potansiyel korku kaynağını ortaya çıkardı. İnsanları korku dolu mesajlar kullanarak ikna etmeye gitti. Korku çekiciliği, bu anlayışın bir sonucudur ve genellikle reklamc1lık söz konusu olduğunda bir ikna şekli olarak kullanılır (Erol, 2017).

Korku çekiciliği insanlara, mesajda ileri sürülen tavsiyelere uymadıklarında başlarına gelecek olumsuz sonuçlara işaret ederek, onları korku yoluyla ikna etmeye çalışan bir mesaj türüdür. Örneğin, uyuşturucudan korunma, sigarayı bırakma ya da doğrudan rakibi hedef alan bir negatif saldırı reklamında, insanlara öncelikle maruz kalacakları olumsuzluklar veya kötü sonuçlar gösterilmekte, daha sonra çözüm önerileri sıralanmakta ve sonuçta kişilerin ikna edici kaynağın isteği doğrultusunda hareket etmeleri istenmektedir (Balcı, 2007). Korku çekicilikleri çoğunlukla canlı, kişiselleştirilmiş veya kanlı resimlerin bol miktarlarda kullanıldığı "korkutucu içeriğe" sahiptir. Bundan başka korku çekicilikleri, uyanan veya hedef kitle tarafindan yaşanan (yani fizyolojik ya da psikolojik) korku miktarı açısından da tanımlanmaya çalışılmıştır (Çakar, 2009). Bir başka deyişle, korku çekiciliği belirli bir davranışın sonucunda oluşabilecek olumsuz ve tehdit edici sonuçların altını çizen ikna etmeye yönelik mesajlar olarak ifade edilmektedir. (Nurlu ve Kuru, 2014). Korku çekiciliği kapsamında, mesajları kullanılırken görsellerden de yararlanmak etkili olur. Mesaj, dikkat çekmeli, tehlike anında düşünülmesini sağlamalı ve korku uyandırmalıdır. Bunu sağlamak için zaman zaman dehşet içeren görüntüler tercih edilmektedir. Ayrıca, bu tür korku mesaj1 içeren mesajlar, mesajda gösterilen tehditten kurtulmak için gerekli görülen davranışlara da vurgu yapmalıdır (Fırat, 2013).

\section{KORKU PAZARLAMASI}


Günümüz dünyası son derece çarpıcı bir paradoksa tanıklık etmektedir. Ekolojik kriz, silahlanma, kapitalizm ve neoliberal sürecin getirdiği sosyal devletin erozyonu vb. son derece ciddi ve gerçek problemler göz ard1 edilirken, korkular s1kl1kla yersiz olana kaymakta ve aslında korkulmas1 gereken olduğu gibi kalırken ve hatta korkulması gereken daha ciddi sorunlar beklerken abartılmış korkulara yenik düşülmektedir. Aslında korkulmaması gereken aşırı abartılmış korkuların pompalanması sonucu yanlış şeylerden korkma durumu söz konusu olmaktadır (Kaya, 2012). Korku literatürü, bir tepki olan korku kavramı ile bir uyarıcı olan tehdit kavramlarını birleştirme eğiliminden genellikle zorlanmaktadır. Uyaran materyallerin korkuyu nasıl uyandırdığını, yüksek, orta ve düşük düzeydeki tehditlerin gerçekte ne olduğu konusunda net olmayan yaygın bir başarısızlık söz konusudur (Hastings ve Stead, 2004). Korku öğesi insanlara önerilen ya da tavsiye edilen şeylere uymadıklarında başlarına gelebilecek olumsuz şeylere dikkati çekerek, korku yoluyla ikna etmeye çalışan bir mesaj türüdür. Günümüzde korku; bir malın pazarlamasından, bir fikre yönelik ikna edici mesajların oluşturulmasına; sosyal alanda bir davranışın değiştirilmesinden, bir fikrin benimsetilmesine veya sosyal sorunlara dikkat çekilmesi gibi birçok farklı amaçla kullanılmaktadır. Korku öğesinin en yaygın kullanıldı̆̆ı alanlardan birisi de sağlık konusundaki ikna edici iletişim süreçleridir. Sağlıkla ilgili davranış değişimini amaçlayan sağlık iletişiminde, insanların sağlık risklerini tanımaları, kendi sağlıklarını geliştirmeleri, erken teşhis ve tedaviye ulaşmaları ve sağlık risklerini azaltmaları amacıyla çeşitli mesaj stratejileri kullanılmaktadır (Ardıç Çobaner, 2013).

Pazarlama ve satışın genel tanımına bakıldığında; tüketici ihtiyaçları doğrultusunda üretim yapmaktır. Bu tanımdan yola çıkılırsa tüketicinin ihtiyacı olmasa bile insan eliyle yapılan sanal felaketlerle insanlar korkutulur ve ihtiyacı olması sağlanır. Korku pazarlamanın geldiği son noktalardan birisi de, üretilmiş olan şeye ihtiyacın olması sağlanmasıdır (Öztürk ve Sevinç, 2017). Korkunun gücünden pazarlama amaçlı yararlanma olarak tanımlanan korku pazarlaması son zamanlarda kozmetik, temizlik ürünleri ve hatta siyasete kadar pek çok alanda kullanılmaktadır (Fırat, 2013). Korku pazarlamasının tarihçesine bakıldığında, 1920'li yıllarda Listerine (ağız 
gargarası) adlı ürüne ait reklam kampanyası olduğu söylenebilir. Rogers'ın Koruma Motivasyon Teorisi korku pazarlaması alanında öncü bir çalışmadır. $\mathrm{Bu}$ araştırmaya göre, insanlar kendilerini fiziksel, psikolojik ve sosyal tehditlerden korumak için motive olmalıdır. Yeni bir tehditle karşılaşıldığında, bu dört değişkene dayanan bir başa çıkma değerlendirmesi başlatır; tehdidin ciddiyeti, herhangi bir uyarlanabilir davranış yapılmadığında meydana gelen tehdidin olasılığı, bir başa çıkma yanıtının (çözüm) mevcudiyeti ve bireyin baş etme davranışını yerine getirme yeteneği şeklinde teori açıklamak mümkündür (Oakley, 2017).

Korku pazarlaması, yıllardır çeşitli reklamlarda başarı bir biçimde kullanılmış ve korku, suçluluk ve utanç arasındaki sonuçlarda farklılıklar bulunmuştur. Birçok araştırmada, reklam kampanyalarındaki korku veya tehdit unsurlarına odaklanılmakta ve bu unsurlarla başa çıkma, tutumlardaki değişiklikler ve davranışsal değişimleri nasıl etkileyebileceğine odaklanmaktadır. Korku pazarlaması fiziksel ve sosyal korku alt kategorilere ayrılabilir; fiziksel korku, bedeni etkileyebilecek tehditler ile ilgilidir. Sosyal korku ise, reklamcılığın etkisini değerlendirmezken sosyal kabul ile bağlantılı tehditler ile ilgilidir. Bu tür başa çıkma davranışları duygu odaklı veya problem odaklı olabilir ve öz-yeterlik, algılanan şiddete ve algılanan olasıllı̆a bağlıdır (Brennan ve Binney, 2010). Günümüz küresel iş ve politika dünyasında veya ticaretinde korku pazarlaması yadsınamaz bir öneme sahiptir. Korku pazarlamasının beslendiği kaynak ise, güvensizlik olmaktadır. Güvensizliğin ana yönlendiricisi olarak iletişim teknolojisi ve özellikle medya ifade edilmektedir. Korku pazarlaması, olan veya olası amaçlara ulaşmak için korkunun ideolojik aygitları ile toplumun veya insanların zihnini ve bilincini körelterek, düşünceleri ve davranışları öngörme, biçimlendirme, yönlendirme ve yönetme sürecidir (Papatya, 2010).

\section{KORKU, EĞLENCE VE OYUN}

Eğlence, yenidünya ekonomisinin hızla gelişen alanlarından biridir. Eğlenceyi bir ürün (hizmet) olarak sunan sektör ise 'eğlence endüstrisi' dir. Modern eğlence endüstrisi, müzik, kitap, sinema, televizyon, radyo, internet, elektronik oyunlar, tiyatro, moda, spor, sanat, ticari ürün satışı ve anlaşmaların 
yanı sıra telif hakları ve ticari markaların bütününden oluşan bir alandır (Çakmak ve Cengiz, 2016). Modern eğlence anlayışının bugünkü konumuna gelmesinde ise geçmiş toplumlardan günümüze aktarılan kültür birikimi önemli bir rol oynamaktadır. Bu kültürel birikimin başlangıcında özellikle halk edebiyatı gelmektedir. Halk edebiyatı, mitoloji, halk hikayeleri, masallar, efsaneler ve fikralardan oluşmaktadır. Korkunun insanlar üzerindeki olumsuz etkilerinin olduğu gibi bu durumu tersine çevirerek eğlence amaçlı kullanımı da yadsınmaz bir gerçektir. Korku, bir eğlence türü olarak karşımıza ilk kez halk edebiyatı eserlerinde özelliklede mitolojide ortaya çıkmaktadır. İlk insanlar için yaşadığı tabiat, diğer insanlar, topluluklar hayatta kalabilmek açısından korku kaynă̆ıdır. Çünkü doğal olayların izahını, modern bilimle açıklayan modern toplumun insanına göre, korkulara dayalı olarak yapar. Mesela şimşeğin çakması, modern insan için bulutlarda biriken elektrik yükünün boşalmasıdır. Hâlbuki ilk insanlar bunu, gökte bulunan bir şimşek tanrısının veya kutsal ruhun insanları cezalandırmak için yaptığı şeklinde açıklar. İşte mitolojinin başlangıç noktası da burasıdır. Doğal olgular, nesneler, bir kişilik ve işlev üstlenerek, gökteki kutsal varlıkların yaptırım gücüyle birleşip mitolojiyi oluştururlar (Kaya, 2017). Mitoloji sözcüğünün kaynağı mit sözcügüdür. Mit (mythe) Fransızca bir terim olup geleneksel olarak yayılan veya toplumun hayal gücü ile biçim değiştiren tanrı, yarı tanrı, tanrıça, evrenin yaratılışı ile ilgili hayali, alegorik, bir anlatımı olan halk hikayesi, mitos olarak tanımlanabilir. Aynı zamanda mitoloji, "mitlerin doğuşlarını, anlamlarını yorumlayan, inceleyen bilim", "bir ulusa, bir dine, özellikle Yunan ve Latin uygarlığına ait mitlerin" ve "olay, fabl, kurgu" karşı1lığ olarak kullanılmaktadır (Bayman, 2010).

Eski toplumların tümünde birbirine benzer ve hatta aynı mitolojik varlıklar ile ilgili olayları anlatan hikayeler, masallar vb. halk edebiyatına ait eserler geçmişte olduğu gibi günümüzde de rağbet görmeye devam etmektedir. Özelliklede mitolojik hikayelerin korkularla ve kahramanlıklarla dolu olması, insanların bilinmezliğe karşı duyduğu yoğun ilgiyi tetikleyerek, her çağda ilgi odağı olmayı başarmaktadır. Halk edebiyatında var olan bu mitolojik hikayeler, toplumların modernleşmesi sürecine uyum sağlayarak, yeni sanat-eğlence türlerinin ortaya çıkmasında ve gelişmesinde etkili 
olmuştur. Halk edebiyatının etkilediği başlıca sanat-eğlence türleri, tiyatro oyunları, yazılı edebiyat eserleri ve sinema filmleri olarak siralanabilir. Halk edebiyatından etkilenerek ortaya çıkan eğlence türlerinden ilki tiyatrodur. Tiyatro, bir öykünün, oyuncu denilen bir yerde canlandırılması ya da hayatta var olabilecek şeylerin sahnede canlandırılmasıdır (Buttanrı, 2011). Bir başka tanıma göre ise, geniş insan topluluklarına ulaşabilme imkânı sağlayan sanatsal türe tiyatro denir. Tiyatro oyunları, komedi, dram, trajedi gibi çeşitli biçimlerde sergilenmektedir. Özellikle trajedi oyunları içinde korku unsurunu barındıran özel bir türdür. Trajedi; acı, korku, coşku uyandıran konuları sergileyerek insan ruhunu tutkulardan arıtmak, kötülüklerden uzak tutmak, kalplerini sevgi ve merhamet duygularıyla donatmak amacı güden oyunlar olarak tanımlamak mümkündür (Arıkan, 2006).

İnsanların yazıyı kullanmaya başlaması ile birlikte, sözlü edebiyat yerini yazılı edebiyata bırakmış ve özellikle 15. yüzyılın başlarında Gutenberg'in matbaa makinesini icadı ile birlikte, halk edebiyatı türlerine ait anlatılar bu kapsamda kitaplaşmaya başlamıştır. Halk edebiyatından etkilenerek ortaya çıkan sanat-eğlence türlerinden bir diğeri ise yazılı edebiyat eserleridir. Yazılı edebiyata ait ilk korku eserlerine bakıldığında 18. yüzyıl Gotik korkusu, bu kaynaklara, Horace Walpole'un 1764 yılında yayımladığ 1 The Castle of Otranto (Otranto Kalesi) adındaki eseri ile karşımıza çıkar. Bu eser, o güne kadar yayımlanmış eserler arasında gerçekçilikten ziyade doğaüstü öğelere yer veren ilk eser olmuştur. Aslında, eserin basılan ilk sürümü, İtalya'da bulunan ve hayali bir çevirmen tarafından yayımlanan bir orta çağ romanı olarak tanıtıldı. Önceleri modern olarak görülse de o dönemde yaşayan pek çok kişi eseri zevksiz buldu ancak eser kısa sürede büyük bir popülerlik kazandı. Gotik geleneği, modern okurların korku edebiyatı olarak adlandırdıkları türe 19. yüzyılda giriş yaptı. Günümüz film ve sinema endüstrisindeki karakterlere ve çalışmalara ilham vermeye devam eden ilk eserler arasinda Mary Shelley'nin 1818 tarihli Frankenstein isimli eseri, Edgar Allan Poe'nun çalışmaları, Sheridan Le Fanu'nun çalışmaları, Robert Louis Stevenson'ın 1886 yılında yazdığı Strange Cases of Dr Jekyl ve Mr. Hyde isimli eseri, Oscar Wilde'ın 1890 yılında yazdığı Dorian Gray'in Portresi isimli eseri ve Bram Stoker'ın 1897 tarihli Drakula isimli eseri yer alır. Tüm bu 
romanlar, günümüz sahne ve sinema eserlerinin ilham aldığı kalıcı birer simge konumundadırlar (Korku Kurgu, 2018).

Başta halk edebiyatı olmak üzere hem tiyatro oyunlarından hem de yazılı edebiyat eserlerinden etkilenerek bunları beyaz perdede insanlara görsellik kazandıran sunan sinema filmleri, korkuyu eğlence sektörü kapsamında insanlara en iyi biçimde aktarma firsatı bulmuştur. Sinemaya bakıldığında korku filmleri, adından da anlaşılabileceği gibi izleyicilerde korku uyandıran kişileri, olayları, durumları işleyen bir türdür. Korkunç olaylar, vampirler, hortlaklar, hayaletler, kurt adamlar, acayip yaratıklar bu tür filmlerin başlıca öğeleridir. İnsanoğlunun korkularından, kuşkularından, giderek batıl inançlarından, değişik folklorundan kaynaklanan, hayal gücüyle beslenen bu konular, durumlar ve güçler fantastiğe dayalı korku sinemasının temelini oluşturmaktadır (Tutar, 2015). Bir başka tanıma göre ise, temelde korkuyu hedef alan, korku öğelerini barındıran ve korkunun belirleyici unsurlarını (şiddet, gerilim, tehlike vb.) taşıyan filmlerin oluşturduğu tür korku sineması olarak nitelenebilir. Diğer türler gibi sessiz dönemden kalma klasik yapitlara ve uzun bir edebiyat geleneğine, bir mirasa sahiptir. Korku sinemas1; ölümsüz mitoslarla beslenen, var olanlara başkaca ve yeni mitoslar ekleyen büyük bir gelenektir (Aytekin, 2013).

İlk korku filmleri geleneksel batı inanç kaynaklarından beslenerek şeytan, cad1, vampir gibi imgeler üzerinden kurgulanmıştır (Şimşek, 2013). Sinema tanımına uygun ilk film olan Arrival of a Train at La Ciotat (La Ciotat'ta Bir Trenin Gelişi) 1895 yılında Lumiere kardeşler tarafından çekilmesinden sonra tarihin ilk korku filmi bundan sadece bir yıl sonra George Melies tarafından çekilmiştir (Tarihin İlk Korku Filmi, 2018). 1896 yılında, fantastik sinemanın öncüsü Georges Méliès'nin ilk filmi olan Le Manoir du Diable (Şeytan Kalesi) filmi korku sinemasının öncüsü olarak kabul edilir. Méliès, ilk filminin ardından "Şeytan ve Faust" gibi yapıtlarla, korku filmlerine devam eder (Şimşek, 2013). Korku edebiyat1, korku sineması, korku objeleri, düzenekli korku atmosferleri ve korku sporu (ekstrem sporlar) insanların ilgisini tarih boyunca her zaman çekmeyi başarmıştır. İnsanlar heyecanlanmaktan, vücutlarındaki adrenalinin artmasından zevk alırlar. Salgılanan adrenalinin artmasında korku oyunları, ekstrem sporlar ve eğlence 
parklardaki oyuncaklar oldukça önemli bir işleve sahiptir (Canabakan, 2017). İsmi daha çok heyecan verici ve korkutucu durumlarda anılan adrenalin, bir hormon türüdür ve böbrek üstü bezleri tarafından salgılanır. Stres, korku ve şok gibi durumlarda salgılanan bu hormonun bazı durumlarda, salgılanması üst düzeye çıkmaktadır. Bu durumlar ise, heyecan ve korku durumlarıdır. $\mathrm{Bu}$ durumlar yaşanırken, vücutta noradrenalin salgılanır ve organizmanın sakinleşmesi sağlanır. Yine bu sakinleşmenin yanında kan damarları genişler. Kan basıncının artması, kalp atış hızının artması, göz bebeklerinin büyümesi ve kan şekerinin yükselmesi, adrenalin salgılandığında oluşan diğer olaylardır. Bu hormonlar, salgılandığında organizma tehlikelere karşı dikkatli bir hale gelmektedir (Gül, 2018). Adrenalin hormonu için kısaca heyecan hormonu da denilmektedir. Bu hormonun korku üzerindeki etkisi oldukça önemli olmakta birlikte, korku sürecinde insan vücudunda yalnız hareket etmez. Kendi ile birlikte mutluluk hormonu olarak da bilinen serotonin hormonu da harekete geçerir.

Mutluluk üzerine yapılan fizyolojik çalışmalarda, mutluluğu sağlayan çeşitli hormonlar olmakla birlikte, mutlulukla en fazla ilişkilendirilen hormonlardan biri serotonin hormonudur. Günlük dilde mutluluk hormonu olarak da adlandırılan serotonin, bireye enerjik olma hissi, sakinlik ve mutluluk vermektedir. Beynin serotonin hormonunu salgilamasıyla mutlu olunurken, serotonin hormonunun azalması ise ruhsal değişimlere ve depresyona neden olmaktadır. Yaşamdan zevk almayı sağlayan serotoninin salgılanmasında bireyin genel ruhsal durumundan, alışkanlıklarına ve beslendiği gıdalara, ne kadar güneş ışığına maruz kaldığına hatta iklimsel koşullara dek pek çok faktör etkili olmaktadır. Fizyolojik açıdan düşünüldüğünde beynin seretonin salgılamasıyla başlayan mutluluk sürecine psikolojik açıdan bakıldığında serotoninin salgılanmasını sağlayacak koşulların ortaya konulmasının gerekliliği görülmektedir. Bu noktada serotonin salgısını başlatarak bireyin mutlu olmasını sağlayacak koşullar ya da faktörler; bireyin kendisini güvende ve iyi hissetmesinden, alışkanlıklarını sürdürmesine ve mutluluk ile özdeşleştirdiği metaları edinmesine değin pek çok farklı özellikle karşımıza çıkmaktadır (Baysal ve Aka, 2013). Bu iki hormonun bir araya gelmesiyle, insan psikolojisi ve fizyolojisi üzerindeki 
etkisi sonucunda adına adrenalin bağımlılığı da denilen korku ihtiyacı ortaya çıkmaktadır.

İnsanları yüzyıllar boyunca başta halk edebiyatı olmak üzere çeşitli sanat-eğlence türleri ile etkisi altında alan korku, zamanla arzulanan bir ihtiyaç halini almıştır. Korkunun bir ihtiyaç olarak ortaya çıkmasında, insanların meydan okuma, cesaret gösterisi, güçlü olma arzusu, kendini kanıtlama veya korkularıyla yüzleşme gibi çeşitli psiko-sosyal nedenlerin etkili olduğu bilinmektedir. Kurku ihtiyacını gidermek için günümüzde bireyler eğlence parklarında yer alan koku oyunları, ekstrem sporlar olarak adlandırılan riski yüksek sporlar ve gelişen teknoloji sayesinde her an her yerde ulaşma şansı bulduğumuz (televizyon, internet, cep telefonu vb.) dijital oyunlar aracılığı ile giderme imkanı bulmaktadır. Ekstrem sporlar, ruh çağırma tahtası, kulaktan kulağa anlatılan cin-hayalet hikayeleri, eğlence parklarında yer alan korku tünelleri gibi sayısız öğe, insanlığın sosyal ve kültürel alanının ayrılmaz bir parçası haline gelmiş durumdadır. Dahası insanlar her geçen gün daha fazla bu korku öğelerini talep etmektedir. (Kabacaoğlu, 2016). Bu kapsamda eğlence parklarındaki korku oyunların var oluşu oldukça büyük bir önem arz etmektedir. İnsanlar tarafından uygulanan ilk korku oyunu örneklerini eğlence parklarında görmek mümkündür. Eğlence parklarının kökeni, Ortaçağ Avrupa şehirlerinde ortaya çıkan mutluluk bahçelerine kadar uzanmaktadır. Bu bahçeler, canlı eğlencenin, ateş oyunlarının, dansın, oyuncaklı oyunların ve hatta ilkel korku trenlerinin varlığıyla bugünün eğlence parklarının referans noktası olmuştur. Parkların vazgeçilmezlerinden biri olan korku etkinlikleri çok çeşitlidir. Ziyaretçilerin gerek yaya olarak gerekse bir araç içerisindekilere geçtikleri perili köşkler, hayaletli evler, korkunç mağaralar, yaratıklar gibi çeşitli birimlerden oluşan mekanlarda yapay donatılarla ziyaretçiler üzerinde korku duygusunu tattırarak adrenalini yükseltilmesi amaçlanmaktadır (Dalkılıç, 2007).

Korku ihtiyacını karşılamak için seçilen bir diğer oyun çeşidi ise ekstrem sporlardır. Geleneksel spor branşlarının aksine içerisinde daha çok bireysel spor branşlarını barındıran ve risk olgusunun ön planda tutan ekstrem sporlar dünya genelinde hızla yaygınlaşmaktadır (Şimşek-1, 2010). Ekstrem spor kavramı literatürde riskli spor, yüksek riskli spor, macera sporları, 
hareket sporları ve adrenalin sporları gibi oldukça değişik biçimlerde adlandırılmaktadır. (Şimşek-2, 2010). Ekstrem sporlarda katılımcılar tarafından risk alma durumu vurgulanmaktadır ve bu branşlar çoğunlukla bireysel sporlardan oluşmaktadır. Katılımcılar yüksek düzeydeki uyarılma, adrenalin, saldırganlık, heyecan, mücadele, benzersizlik, psikolojik durum, fiziksel-manevi rahatlık ve başarma gibi özelliklerden güdülenmektedir (Şimşek-1, 2010).

\section{KAÇIŞ VE KORKU EVİ OYUNLARI}

Korku insanların kaç ya da kavga et tepkisini tetikleyen bir duygudur ve karşı karşıya kalınan tehditle başa çıkmayı sağlar. Ancak korku temalı bir aktivite içerisindeyken aslında tehdit altında olmadığınızı bilirsiniz ve hissettiğiniz adrenalin eğlenceli bir hal alır (FPDME, 2017). Yeni oyunlar ile korkuyu dahi eğlence aracı olarak kullanan dünya eğlence sektörü, kentlerdeki eğlence sistemini sürekli olarak değişime zorlamaktadır (Özdemir, 2005). Bu kapsamda oyunun, kendiliğinden ortaya çıkan zevk için yapılan, bir düzenleme içermeyen eğlenceli bir davranış olarak ele alarak, bilişsel gelişimin bir paçası olarak tanımlayabiliriz. Ayrıca, oyun bireyin çevre ile baş edebilmesi için kullandığı bir mekanizma olarak tanımlanmaktadır (Ardahan, 2017). Bir başka tanıma göre ise oyun, vakit geçirmeye yarayan, belli kuralları olan eğlence olarak tanımlanırken, elektronik oyunlar ise bilgisayar ve konsol yardımı ile oynan; hoş, eğlenceli, rekabetçi ve interaktif zaman geçirmeyi sağlayan bir aktivite olarak tanımlanabilir.

Oyun türlerine bakıldığında ise, çevrim içi (online) ve çevrim dışı (offline) biçiminde oynanmaktadır. Oyunlar, tek kişilik, çok kişili, cihaza karşı (bilgisayar, konsol, cep telefonu, tablet vb.) veya internet aracıllığı ile oynanan online oyunları kapsamaktadır (Argan, 2007). Teknolojinin ilerlemesiyle popülerliği artan elektronik oyun sektöründe de korku teması fazlasıyla ele alınmaktadır. Elektronik oyunları etkileşimli bir içerik sunması sayesinde, korku dâhil pek çok duyguyu filmlere göre daha etkili biçimde kişiye yansıtabilme avantajına sahiptir. Bu nedenle her yıl çok sayıda insan, eğlenceye ayırdığı zamanı elektronik oyunlarla geçirir (Kabacaoğlu, 2016). Korku oyunları tarihine bakıldığında, temellerinin korku-kurgulama yani 
korku romanlarına ve korku sinemasına dayandığını görülür. Korku alanında, roman yazarı Howard Phillips Lovecraft'in Cthulhu Mitosu; psikolojik ve kurgusal korku türünün temelini oluşturur. Yazarın ilk defa korkuya bilim kurgu öğelerini katması da bu alanda önem arz etmektedir. Bugün büyük kitleleri peşinden koşturan korku oyunlarının temelleri, Cthulhu mitosları ile Japon ve Amerikan korku sineması arasında şekillenmeye başlamıştır. Sinema dalında Amerika yapımlı çeşitli psikopat seri katil filmleri ve Japon korku sinemasının da korku oyunlarına çok önemli etkileri olmuştur (Ilgın, 2018).

Bireylerin kendilerinin ürettiği veya başkaları tarafından üretilen, ücretli ve/veya ücretsiz birçok ürün yaşamımızda eğlence ürünü olarak yer almaktadır. Rekreatif etkinliklerin tamamı eğlence aracı olarak kullanılmakta ve bu sebeple sanat, spor, eğlence vb. dâhil olmak üzere eğlence mekânlarında gerçekleştirilen (sinema, tiyatro, internet, elektronik oyunlar vb.) tüm aktivitelerin birer eğlence ürünü olduğu söylenebilir. Eğlence pasif katılımı olabileceği gibi aktif katılımlıda olabilir. Aktif eğlencede bireyin kendisi eğlence ürünü üretmesi sürecine dâhildir. Kendisi üretebileceği gibi hizmet niteliğindeki eğlence hizmetini ücretli ve/veya ücretsiz olarak başkalarından alabilir (Ardahan, 2016). Bireysel tercihlere yönelik hizmet eden rekreasyon işletmelerine bakıldığında. Bireysel tercihlere yönelik hizmet eden rekreatif işletmeler, insanların boş zamanlarını değerlendirmek üzere yalnızca bireysel tercihlerini veya münferit amaçlı olarak haz alabileceği herhangi bir etkinlik içerisinde bulunması olarak tanımlanabilir. $\mathrm{Bu}$ kapsamda yapılabilecek rekreatif faaliyetlerin sınırlandırılması ya da ifade edilmesi oldukça zordur. Ancak, bireyin yalnız başına yapabileceği, sanat, spor, eğlence gibi diğer alanların dışındaki rekreatif faaliyetler olarak tanımlanabilir. Bu kapsamda faaliyetlerin yapılabileceği mekânlar ise bireysel tercihlere yönelik hizmet eden rekreatif işletmeler olarak adlandırılabilir (Yaylı, 2014).

Kaçış ve korku evi oyunları ortaya çıkışı diğer korku eğlence türlerinde olduğu gibi başta halk edebiyatı olmak üzere tiyatro oyunları, yazılı edebiyat eserleri, sinema filmleri ve özellikle de elektronik oyunlar gibi birçok öncüden etkilenmiştir. Halk edebiyatı eserlerinde var olan doğaüstü, korkunç vb. varlıklar sonraki süreçte tiyatro oyunlarına, yazılı edebiyat eserlerine ve sinema filmlerine nasıl ilham kaynağı olduysa, elektronik korku oyunları da 
aynı şekilde kaçış ve korku evi oyunlarının ortaya çıkmasında ilham kaynağı olmuştur.

Günümüzdeki anlamı ile ortaya çıkan ilk kaçış ve korku evi oyunu, 2007 yılında Takao KATO tarafindan Scrap Co. (Scrap Şirketi) bünyesinde oluşturulmuş ve Japonya'nın Kyoto şehrinde Real Escape Game (Gerçek Kaçış Oyunu) adıyla ortaya çıkmıştır. Kaçış ve korku evi oyunları, Japonya ve diğer Uzak Doğu ülkelerinde, okul, yıkılmış hastane, eğlence parkları, stadyum, kilise gibi farklı yerlerde gerçekleştirilmiştir. Ayrıca, Japonya'daki Gerçek Kaçış Oyunu hem televizyon dizisi hem de film serisi olarak yayınlanmıştır. Japonya merkezli Scrap Şirketi, ABD'de Scrap Entertainment Inc. (Scarp Eğlence Şirketi) adı altında şube açmış ve bu kapsamda ilk kaçış oyununu 2012'de San Francisco'da oynanmıştır. Bu kaçış oyunu, gemide gerçekleşen ilk kaçış oyunu olarak tarihe geçmiştir. (Real Escape Game, 2018). Ülkemizde ise ilk kaçış ve korku evi oyunu 2013 yılında İstanbul'da faaliyete geçmiştir. Bunu takip eden zaman içerisinde başta büyükşehirler olmak üzere hemen hemen tüm şehirlerimizde, hatta nüfusu 15-16 bin olan ilçelerde dahi kaçış ve korku evi işletmesi bulunmakladır. Nisan 2018 tarihi itibari ile ülkemizde internet üzerinden web sitesi ve/veya facebook hesabı bulunan yaklaşı 200 adet kaçış ve korku evi işletmesi faaliyet gösterdiği tespit edilmiştir.

Kaçış oyunlarını genellikle belli bir süre içinde bir odadan veya evden belli zekâ oyunları oynayarak veya şifreler çözerek çıkmaya çalışmak olarak açıklanabilir. Kaçış oyunları arasında en çok tercih edilenleri ise korku temalı olan, korku evi oyunlarıdır. Bu oyunlarda da tema genellikle kurgulanmış bir senaryo kapsamında, karanlık ve korkunç yerlerde, canlı veya cansız olarak kullanılan korkutucu figürler ile diğer kaçış oyunlarındakilere benzer etapları tamamlama şeklinde oynanır (Üçhisarlı, 2017). Kaçış ve korku evi oyunlarına detaylı bir şekilde bakıldığında, bu oyunların uygulamasında işletmeler arsında farklılıklar görülmektedir. Bu farklılıklar genel olarak kaçış ve korku evi oyunlarının uygulanması esnasında ortaya çıkan, oyun süresi, oda sayısı, oyun senaryoları, oyuncu sayısı ve işletmeye ait personel sayısı olarak sıralanabilir. Bu farklılıkların başında oyun süresi gelmektedir. Bu oyunların 
uygulama süreleri genellikle 45-60 dakika arasında sürmektedir (oyun esnasinda katılımcılardan biri veya tamamının oyunun durdurulmasımı istemesi, katılımcıların fenalaşması, oyun ve işletme kurallarına uyulmaması vb. olaylar nedeniyle daha öncede bitebilir). Kaçış ve korku evi oyunları arasındaki bir diğer fark ise, oyunun uygulandığı oda sayısıdır. Bu durum işletmenin oyun kurgusuna bağlı olarak 5-10 oda arasında değişiklik göstermektedir. Kaçış ve korku evi oyunları arasındaki bir diğer fark ise, bu oyunlardaki oyun kurgusudur. Bu kurguların bazıları, korku edebiyatı eserlerinden, korku filmlerinden ve elektronik korku oyunları senaryolarından uyarlanabildikleri gibi bazıları da bu işletmelerin çalışanları tarafından oluşturulmuş özgün kurgular olarak karşımıza çıkmaktadır. Bu kurgusal oyun esnasında oyuncular her odada, oyun içeriğine bağlı olarak sıralı bir şekilde diğer odalara geçmek ve oyunu istenen süre içerisinde bitirmek amacı ile birbirinden farklı zekâ oyunları (bilmece, bulmaca, yapboz, şifre çözme vb.) oynamaktadırlar.

Ayrıca, bu oyunlar esnasında oyuncular sadece zekâ oyunları ile karşılaşmamaktadır. Oyuncular, oyunun kurgusu kapsamında hem kontrol odasından bilgisayarlar aracılığ 1 ile uzaktan hem de işletme çalışanlarınca oyun alnında yakından, ses efektleri, resimler, ışık oyunları, şok cihazları vb. uyarıcılar aracılığı ile korkutulmaktadır. Kaçış ve korku evi oyunları arasındaki farklardan bir diğeri de oyuncu sayısıdır. İşletmeler hem oyun kurgularının kapsamı hem de oyun uygulama alanının genişliğine bağlı olarak, oyuna aynı anda 2-6 oyuncu birlikte başlamaktadır. Kaçış ve korku evi oyunları arasındaki bir diğer fark ise, işletmedeki çalışan sayısıdır. Genellikle bu işletmelerdeki çalışan sayısı, biri kontrol odasında ikisi oyun uygulama alanında olmak üzere toplam üç personel ile sınırlıyken, bazı işletmelerde ise bu sayısı on personelden fazla olabilmektedir.

Kaçış ve korku evi işletmelerinin giderlerine bakıldığında, mekân kiralar1, reklam, elektrik, kurgusal oyun malzemeleri, personel ücretleri olarak sıralayabiliriz. Bunların yanı sıra bazı yeni işletmeler, sektörde yer alan diğer işletmelerden ücret karşıllı̆ında kurgusal senaryolar da satın almaktadır. Kaçış ve korku evi işletmelerinin gelirlerine bakıldığında ise, tek gelir kaleminin katılımcılardan alınan oyun ücretleri olduğu söylemek yerinde olur. 
Ülkemizde kaçış ve korku evi açma ruhsatı alabilmek için tam anlımı ile bir yasal düzenleme bulunmamaktadır. Kaçış ve korku evi işletmeleri, faaliyette bulunmak için (5393 Sayılı Belediye Kanunu'nun 15. Maddesi'nin "l” Bendi ve 5216 Sayılı Büyükşehir Belediye Kanunu'nun 7. Maddesi’nin “u” Bendi) İşyeri Açma ve Çalışma Ruhsatlarına İlişkin Yönetmelik (2005/9207) kapsamında; 4. Madde'nin "a” Bendi'ne göre, "belediye sınırları ve mücavir alanlar dışı ile kanunlarda münhasıran il özel idaresine yetki verilen hususlarda il özel idaresini; büyükşehir belediyesi sınırları ve mücavir alanlar içinde büyükşehir belediyesinin yetkili olduğu konularda büyükşehir belediyesini, bunların dışında kalan hususlarda büyükşsehir ilçe veya ilk kademe belediyesini; belediye sınırları ve mücavir alanlar içinde belediyeyi ve organize sanayi bölgesi sınırları içinde organize sanayi bölgesi tüzel kişiliğine tabidir". Ayrıca, 4. Madde'nin "g” Bendi'ne göre ise, "umuma açık istirahat ve eğlence yeri: Kişilerin tek tek veya toplu olarak eğlenmesi, dinlenmesi veya konaklaması için açılan otel, motel, pansiyon, kamping ve benzeri konaklama yerleri; gazino, pavyon, meyhane, bar, birahane, içkili lokanta, taverna ve benzeri içkili yerler; sinema, kahvehane ve kıraathaneler; kumar ve kazanç kastı olmamak şartıyla adı ne olursa olsun bilgi ve maharet artırıcı veya zeka geliştirici nitelikteki elektronik oyun alet ve makinelerinin, video ve televizyon oyunlarının içerisinde bulunduğu elektronik oyun yerleri; internet salonları, lunaparklar, sirkler ve benzeri yerleri kapsamaktadır (Resmi Gazete, 2018). Ancak, bu yasal düzenleme kapsamındaki eksiklikler nedeniyle kaçış ve korku evi işletmeleri, ruhsat veren ilgili yerel yönetimlerce verilen çeşitli isimler adı altında (kıraathane, alkolsüz eğlence merkezi, oyun salonu vb.) faaliyet göstermektedirler.

\section{SONUÇ}

Korku bir eğlence türü olarak ilk kez halk edebiyatına ait eserlerde ortaya çıkmaktadır. Bu eserler toplumsal alandaki gelişmeler sonucunda farklı eğlence türlerinin ortaya çıkması ve gelişmesi açısından önemli bir ilham kaynağı olmuştur. Korkunu oyunlaşması süreci de bu durum ile benzerlik taşımaktadır. Tarihsel sürece bakıldığında özellikle de insanların birebir uygulama esasına bağlı olarak ilk olarak eğlence parklarındaki korku trenleri 
ve korku tünelleri olduğu görülmektedir. Zamanla yeni arayışlar içerisine giren bireyler, ekstrem sporları keşfi ile adrenalinle bir diğer ifadeyle korku ihtiyacı ile tanıştı. Teknoloji alanında yaşanılan gelişmeler elektronik oyun çă̆ını başlattı. Televizyon, video, bilgisayar ve günümüzde özellikle cep telefonu ve tablet oyunları eğlence sektörünün gelişmesine önemli katkı sağladı. Özellikle de elektronik oyunlardan ilham alarak ortaya çıkan kaçış ve korku evi oyunları sanal ortamdan çıkıp bireyin oyunun içinde olduğu yeni bir rekreatif eğlence türü olarak karşımıza çıkmıştır. İnsanları günlük rutin yaşantılarından uzaklaştırarak eğlence ve korkuyu bir arada sunarak özgün bir eğlence anlayışı yaşatmaktadır. Tüm dünyada olduğu gibi ülkemizde de ilgi gören kaçış ve korku evi oyunları, işletmeler arasındaki çeşitlikler sayesinde katılımcılara farklı deneyimler yaşatmaktadır. Bu sayede ülkemizde sadece büyükşehirlerle sınırlı kalmayıp talep görmesi nedeniyle nüfusu 20 binin altında olan ilçelerde dahi açılarak hizmet vermektedir. Özellikle işletmeler arasındaki farklı kurgusal oyun senaryoları bu oyunlara ilgi duyan insanların aynı şehirde bulunan farklı kaçış ve korku evi oyunları oynamalarına ve hatta farklı şehirlerde bulunan kaçış ve korku evi işletmelerine gitmelerine neden olmaktadır. Bu durum kaçış ve korku evi oyunlarının artık bir sektör olduğunu gösterir niteliktedir.

Kaçış ve korku evi oyunlarının, katılımcılar ve işletmeler üzerinde hem olumlu hem de olumsuz yanları olduğu söylenebilir. Bu oyunların, öncelikler olumlu yanlarına bakıldığında; özellikle şehir yaşamındaki kalabalık ortam, çevre kirliliği ve bunlara bağlı birtakım olaylar bireylerde hem fizyolojik hem de psikolojik bir dengesizliğe yol açmakta, bu dengesizliği ortadan kaldırmak için rekreatif etkinliklere ihtiyaç duyulmaktadır. Rekreasyon insanları için bir deşarj aracı ve ruh sağlığının dengeleyici bir unsuru olma özelliği ile giderek bir gereklilik haline geldiği söylenebilir. Özellikle çalışan insan için bu tür etkinliklere başvurmak, onun yeniden enerji kazanması bakımından gereklidir. Gün geçtikçe hayatımıza giren yenilikler eğlence anlayışımızda da kaçış ve korku evi oyunları gibi farklı alternatifler getirmektedir. Kaçı̧ ve korku evi oyunları, adından da anlaşılacağı gibi insanları korku unsuru ile korkuları ile yüzleştirmekte ve onlara bir meydan okumayla birlikte, cesaretlerini sınamalarını sağlama firsatı vermektedir. Aynı zamanda oyun 
içeriğindeki kaçış unsuru sayesinde tam anlamı ile katılımcılara dikkat, çeviklik, esneklik, hızlı düşünme gibi zekâ oyunları oynatarak hem zihinsel hem de fiziksel becerilerini geliştirmektedir. Kaçış ve korku evi oyunlarındaki amaç katılımcıları korkutmak değildir. Bu oyunlardaki asıl amaç her rekreatif faaliyette olduğu gibi katılımcıların boş zamanlarını değerlendirip, eğlendirmek ve haz alarak mutlu olmalarını sağlamaktır. Kaçış ve korku evi ismi her ne kadar bu durumun aksi bir ifadesi gibi duruyor olsa da katılımcilar için benzersiz bir deneyim olduğu söylenebilir.

Kaçış ve korku evi oyunlarının olumsuz yanlarına bakıldığında ise, özellikle ülkemizde kaçış ve korku evi işletmelerinin açılması ve işletilmesi hususunda tam anlamı ile bir yasal düzenleme bulmamaktadır. Bu durum, şuan aktif olarak faaliyet gösteren birçok işletmenin ruhsatsız ve hatta kaçak olduğunu göstermektedir. Ayrıca bu yasal düzenleme konusunda hem ruhsat vermekle yetkili yerel yönetimler hem de işletme sahipleri konuyla ilgi yetersiz kalmaktadır. Oysaki ruhsatsız olarak açılan ve varlığını bu şekilde sürdürmeye devam eden işletmeler, yasal olarak denetimden de muaftırlar. $\mathrm{Bu}$ nedenle elde edilen gelirden vergi verme gibi bir durumları da söz konusu değildir. Ayrıca yine denetimsizlikten dolayı bu yerlerde iş güvenliğine dair bir tedbirde alınmamaktadır. Özellikle kaçış ve korku evi işletmelerinde oyunlarda kullanılan malzemelere bakıldığında, başta odaları birbirinden ayıran veya bağlayan duvarların ahşap oluşu, plastik malzemeden yapılmış manken, maske vb. oyuncaklar, kamera, hoparlör vb. diğer cihazlara ait elektrik kabloları, kumaş, kauçuk vb. çabuk yanan malzemelerin çok kullanılması, özellikle bu işletmelerde yaşanacak olası bir yangın durumunda yangın tüpü, yangın merdiveni ve acil çıkış gibi yönlendirmelerin olmayışı, oyun esnasında meydana gelebilecek büyük bir felaketin yaşanmasına neden olabilir.

Sonuç olarak kaçış ve korku evi oyunlarının ülkemizde bir sektör olarak ilerlemekte olduğu ve rekreasyon hizmetleri alanında yeni bir girişimcilik fırsatı ortaya koyduğu söyleyebilir. Ancak yasal düzenlemelerin eksikliği ve oyunlara ev sahipliği yapan işletmelerin güvenlik önlemlerini almaları bir gereklilik oluşturmaktadır. Türkiye'deki rekreasyon alanındaki lisans 
programları müfredatına kaçış ve korku evi oyunlarına dair içerikler eklenerek turizm işletmeleri başta olmak üzere eğlence ile ilgili diğer sektörler için yeni bir hizmet alanı oluşturacağı öngörülmektedir.

\section{KAYNAKÇA}

Ardahan, F. (2016). Her Yönüyle Rekreasyon, Ardahan, F. Serbest Zaman ve Rekreasyon, Ankara: Detay Yayıncılık.

Ardahan, F. (2017). Açık Alan Rekreasyonu, Ardahan, F. \& Kaplan Kalkan, A. Oyun ve Ritüeller (s.57-67). Ankara: Detay Yayıncılık.

Ardıç Çobaner, A. (2013). Sağlık İletişiminde Korku Öğesinin Kullanımı: Sigara Paketlerinde Kullanılan Sigara Karşıtı Görsellerin Gösterge-bilimsel Analizi, İletişim Kuram ve Araştırma Dergisi, 37, 211-235.

Argan, M. (2007). Eğlence Pazarlamasl, Ankara: Detay Yayıncılık.

Arıkan, Y. (2006). A'dan Z'ye Tiyatro Kılavuzu, İstanbul: Pozitif Yayınları.

Aslan Karakü̧̈ük, S. (2010). Korkunun Kadınları: Cadılar ve Cadıcılık, Sosyoloji Araştırmaları Dergisi, 13(2), 40-64.

Aytekin, M. (2013). Korku Sinemasında Türler, Atatürk Illetişim Dergisi, 5, 63-84.

Balc1, Ş. (2007). Negatif Siyasal Reklamlarda İkna Edici Mesaj Stratejisi Olarak Korku Çekiciliği Kullanımı, Selçuk Üniversitesi Sosyal Bilimler Dergisi, 17, 73-106.

Bayman, H. (2010). Halk Edebiyatı Anlatı Türleri, Ankara: Gazi Kitapevi.

Baysal, S. \& Aka, İ.Ç. (2013). Bir Pazarlama Stratejisi Olarak Mutluluk Temasının Markalar Tarafindan Kullanılması: Mutluluk Temelli Pazarlama Üzerine Bir Araştırma, Sosyal ve Beşeri Bilimler Dergisi, 5(1), 84-93.

Brennan, L. \& Binney, W. (2010). Fear, Guilt and Shame Appeals in Social Marketing, Journal of Business Research, 63, 140-146.

Buttanrı, M. (2011). Çeşitli Yönleriyle Tiyatro, Eskişehir: Osmangazi Üniversitesi Yayınları.

Canabakan, N. (2017). Korku ve Haz, http://www.aktuelpsikoloji.com/ korku-ve-haz 1239yy.htm adresinden alındi.

Çakar, S. (2009). Reklamlarda Korku Çekiciliğinin Kullanılması, Yüksek Lisans Tezi, Bahçeşehir Üniversitesi Sosyal Bilimler Enstitüsü.

Çakmak, A.Ç. \& Cengiz, H.A. (2016). Eğlence Pazarlaması Kapsamında Tüketicilerin Sinema Filmlerine Yönelik Tercihi ve Tatmin Boyutu Üzerine Bir Araştırma: "Fetih 1453" Filmi Örneği, Turkish Journal of Marketing, l(1), 47-75.

Çıplak Coşkun, N. \& Zöhre, H. (2014). Küreselleşme ve Tüketim Kültürünün Yaygınlaşması Bağlamında Türkiye'de Cadılar Bayramı, International Periodical for The Languages, Literature and History of Turkish or Turkic, 9(3), 497-506.

Dalkılıç, E. (2007). Eğlence Parklarının Tarihsel Gelişimi ve Planlama Kriterleri, Yüksek lisans tezi, Ankara Üniversitesi Fen Bilimleri Enstitüsü. 
Dinçer, A. (2017). Korku: Dili, Kavramlaşması, Kültürel Boyutu, Uluslararası Türkçe Edebiyat Kültür Eğitim Dergisi, 6(2), 769-798.

Ergin, M. (2013). Orhun Kitabeleri. İstanbul: Boğaziçi yayınları.

Erol, E.G. (2017). Tv Reklamlarında Korku Çekiciliği Olgusu: 2010-2017 Yılları Arasında Tv Reklamlarına Yönelik Bir Araştırma, İn̈nü Üniversitesi İletişim Fakültesi Elektronik Dergisi, 2(2), 55-67.

Fenomen Psikolojik Danışmanlık ve Eğitim Merkezi (2017). Korku Gecesi, http://www.psikologankara.net/korku-gecesi-insanlar-neden-korkmakister.html adresinden alınd.

Fırat, D. (2013). Korkunun Bir Pazarlama Aracı Olarak Uygulanması: İşletmelerin Korku Mesajları İle Tüketicilerin Algısı Arasında Uyum Var M1, Sosyal ve Beşerî Bilimler Dergisi, 5(1), 187-197.

Hastings, G. \& Stead, M. (2004). Fear, Appeals in Social Marketing: Strategic and Ethical Reasons for Concern, Psychology \& Marketing, 21(11), 961-986.

Gençöz, T. (1998). Korku: Sebepleri, Sonuçları ve Başetme Yolları, Kriz Dergisi, 6(2), 9-16.

Gül, E. (2018). Adrenalin ve Adrenalin Hormonu Nedir, http://www.bilgiustam.com/adrenalin-hormonu-nedir/ adresinden alınd1.

Ilgın, Ö. (2018). Korku Oyunları: Korkunun Oyuncularla Buluşması http://www.multiplayer.com.tr/yazi-dizisi/hayatta-kalma-korku-oyun laribolum-1-korkunun-oyuncularla-bulusmasi/2/ adresinden alınd1.

Kabacaoğlu, G. (2016). Korkuyu Arzulamak: Korku Filmleri, Oyunları ve Romanları Üzerine Kısa Bir Analizi, Türk Psikolojik Danışma ve Rehberlik Bülteni, 4(28), 30-32.

Kaya, M. (2017). Türk Halk Kültüründe Korku, https://muharrem kayamsgsu.tr.gg/Korku.htm adresinden alındı.

Kaya, Ş.Ş. (2012). Sahibinden Satılık Korkular: Kadının Korkutulan Özne Olarak İnşasında Medyanın Rolü, Gaziantep Üniversitesi Sosyal Bilimler Dergisi, 11(1), 191-211.

Kayacı, Ü. (2016). Korkuları Umuda Çevirmek, Türk Psikolojik Danışma ve Rehberlik Bülteni, 4(28), 44-45.

Kaynak, S. (2016). Fobiler, Türk Psikolojik Danışma ve Rehberlik Bülteni, 4(28), 34-35.

Korku Kurgu. (2018). https://ipfs.io/ipfs/QmT5NvUtoM5nWFfrQdVrFtvG fKFmG7AHE8P34isapyhCxX/wiki/Korku_kurgu.html adresinden alındı.

Mazıcı, E.T. \& Çakı, C. (2018). Adolf Hitler'in Korku Çekiciliği Bağlamında Kamu Spotu Reklamlarında Kullanımı, Erciyes Illetişim Dergisi, 5(3), 290-306.

Nurlu, Ö. \& Kuru, O. (2014). Eğitim Fakültesinde Görev Yapan Öğretim Elemanlarının Korku Çekiciliği Kullanma Düzeylerinin Belirlenmesi, The Journal Of Academic Social Science Studies, 30, 515-527. 
Oakley, T. (2017). The Growth of Fear Appeals in Advertising, https:// themarketingagenda.com/2014/09/11/the-growth-of-fear-appeals-inadvertising/ adresinden alınd1.

Özdemir, N. (2005). Cumhuriyet Dönemi Türk Eğlence Kültürü, Ankara: Akçăg Yayınlar1.

Özdemir, N.K. (2016). Bizi Esir Eden Korku ve Kaygılarımız, Türk Psikolojik Danışma ve Rehberlik Bülteni, 4(28), 19-22.

Öztürk, U. \& Sevinç, H. (2017). Korku Pazarlama Çerçevesinde Suriye Hükümeti’nin Silah İthalatını Arttıran Etkenler, Uluslararası Sosyal Araştırmalar Dergisi, 10(54), 990-998.

Papatya, Ş. (2010). Korku Pazarlaması: İronik ve Eleştirel Bir Katkı, Pazarlama ve Iletişim Dergisi, 31, 3-13.

Real Escape Game. (2018). https://realescapegame.com/about/ adresinden alınd1.

Resmi Gazete. (2017). http://www.resmigazete.gov.tr/eskiler/2005/08/ 200508104.htm adresinden alındi.

Şimşek, G. (2013). Siyasi Olayların Korku Sinemasına Yansımaları, Elektronik Sosyal Bilimler Dergisi, 12(46), 264-280.

Şimşek, K.Y. (2010). Dünya Spor Endüstrisinde Ekstrem Sporların Gelişimi ve Yeri, CBÜ Beden Ĕ̆itimi Ve Spor Bilimleri Dergisi, 5(1). 21-27.

Şimşek, K.Y. (2010). Türk Ekstrem Sporcularının Spora Katılım Güdüleri Üzerine Nitel Bir Araştırma, CBÜ Beden Eğitimi Ve Spor Bilimleri Dergisi, 5(3), 107-118.

Tarihin İlk Korku Filmi. (2018). https://seeitwatchit.wordpress.com/2014/03 /03/tarihin-ilk-korku-filmi/ adresinden alındı.

Tutar, C. (2015). Türk Korku Sinemasının Yapısal Engelleri: Sosyo-Kültürel Bir Bakış, Gümüşhane Üniversitesi İletişim Fakültesi Dergisi, 3(2), 247-274.

Türk Dil Kurumu, (2017). http://www.tdk.gov.tr/index.php?option=com_gts \&arama=gts\&guid=TDK.GTS.5af46b39f0cfc4.17967929 adresinden alınd1.

Türk Dil Kurumu, (2017). http://www.tdk.gov.tr/index.php?option=com_dlt vtb\&arama=kelime\&guid=TDK.GTS.5a4e358cc6b0b9.65647761 adresinden alındi.

Türk Dil Kurumu, (2018). http://www.tdk.gov.tr/index.php?option=com_dlt vtb\&arama=kelime\&guid=TDK.GTS.5a4e358cc6b0b9.65647761 adresinden alındi.

Üçhisarlı, C. (2017). İnsanlar Neden Korkutulmak İster, Korkmak İçin Neden Para Öder: http://www.pazarlamasyon.com/pazarlama/insanlar -korkutulmakister-korkmak-icin-para-oder/ adresinden alındı.

Yaylı, A. (2014). Rekreasyona Giriş, Gül, T. Rekreasyon Olgusuna Temel Yaklaşım, Ankara: Detay Yayıncılık. 